\section{Nursing students' motivation and learning strategies}

\section{Hemşirelik öğrencilerinin güdülenme ve öğrenme stratejileri $^{1}$}

\author{
Tuğba Gün ${ }^{2}$ \\ Yildız Denat ${ }^{3}$
}

\section{Özet}

$\mathrm{Bu}$ araştırma, hemşirelik öğrencilerinin güdülenme ve öğrenme stratejileri ile etkileyen etmenleri belirlemek amaciyla yapılmış, tanımlayıcı ve analitik bir çalışmadır.

Araştırmanın örneklemini Türkiye'nin Batısındaki bir üniversitesinin Hemşirelik Bölümü'nde öğrenim görmekte olan 648 öğrenci oluşturdu. Araştırma verileri "Öğrenci Bilgi Formu" ve "Güdülenme ve Öğrenme Stratejileri Ölçeği” ile toplandı. Araştırmada kız öğrencilerin içsel hedef, görev değeri ve sinav kayg1s1, erkek öğrencilerin ise öğrenme kontrolü inancı puan ortalamaları anlamlı derecede yüksek bulundu $(p<0.05)$. 1. sınıf öğrencilerin içsel ve disssal hedef puan ortalamalarının 3. ve 4 . sinıflara göre, öz yeterlilik puan ortalamalarının ise 2. 3. ve 4. sinıflara göre anlamlı düzeyde daha yüksek olduğu saptandı. Hemşirelik mesleğini isteyerek ve kısmen isteyerek seçen öğrencilerin görev değeri, hemşirelik mesleğini isteyenlerin ise ayrıca öz yeterlilik ve sınav kayg1sı, düzenli kitap okuyanların içsel hedef ve öz yeterlilik puan ortalamalarının anlamlı düzeyde yüksek olduğu saptandi. Araştırmaya katılan kız öğrencilerin açımlama ve düzenleme, metabilişsel stratejiler, zaman ve çalışma ortamı yönetimi, erkek öğrencilerin ise akran işbirliği stratejileri anlamlı düzeyde yüksek bulundu.1.sınıf öğrencilerinin açımlama ve

\footnotetext{
${ }^{1}$ Bu makale Aydın Adnan Menderes Üniversitesi Sağlık Bilimleri Enstitüsü Yüksek Lisans Tezi’nden türetilmiştir

2 M.Sc., tugba.kurt1988@,hotmail.com

${ }^{3}$ Doç. Dr., Aydın Adnan Menderes Üniversitesi, Hemşirelik Fakültesi, denat09@gmail.com
} 
Gün, T., \& Denat, Y. (2020). Hemşirelik öğrencilerinin güdülenme ve öğrenme stratejileri. Journal of Human Sciences, 17(1), 32-48. doi:10.14687/jhs.v17i1.5784

time and study environment strategy average scores of the female students participating in the study, and peer learning average scores of the male students participating in the study were found to be significantly high. The average scores of rehearsal, elaboration, organization, critical thinking and metacognitive selfregulation of the student who read books regularly were found to be significantly high. Elaboration, organization, critical thinking and help-seeking score averages of those who did not choose the nursing profession willingly were found to be significantly low $(\mathrm{p}<0.05)$.

As a conclusion, it was found that the nursing students have been motivated mostly by intrinsic goal orientation and least motivated by test anxiety. Moreover, it was noted that gender, grader, willingness in choosing nursing profession and habit of reading books regularly have affected the students' motivation and learning strategies. It is considered that this research will constitute data for other studies and it will be as a guide for the organization of nursing education activities, fulfilling educational goals and providing quality education.

Keywords: Nursing, nursing education, learning, motivation, learning strategies.

(Extended English summary is at the end of this document) eleştirel düşünme, metabilişsel, akran işbirliği yönetimi ve yardım isteme stratejileri, düzenli kitap okuyan öğrencilerin ise yineleme, açımlama, düzenleme, eleştirel düşünme ve metabilişsel stratejileri puan ortalamaları anlamlı düzeyde yüksek bulunmuştur. Hemşirelik mesleğini istemeyerek seçen öğrencilerin açımlama, düzenleme, eleştirel düşünme ve yardım isteme stratejileri puan ortalamalar1 anlamlı derecede düşük saptanmıştır $(\mathrm{p}<0.05)$.

Sonuç olarak hemşirelik öğrencilerinin en fazla içsel hedef, en az sınav kaygısı ile güdülendikleri, cinsiyet, sınıf, hemşirelik mesleğini seçmedeki isteklilik ve düzenli kitap okuma alışkanlığının öğrencilerin güdülenme ve öğrenme stratejilerini etkilediği saptandı. $\mathrm{Bu}$ araştırmanın diğer çalışmalara veri oluşturacağı, hemşirelik eğitimi etkinliklerini düzenleme, eğitim hedeflerine ulaşma ve kaliteli bir eğitim sağlamada yol gösterici olacağı düşünülmektedir.

Anahtar Kelimeler: Hemşirelik, hemşirelik eğitimi, öğrenme, güdülenme, öğrenme stratejisi.

\section{Giriş}

Gelişen ve değişen sağlık bakım sistemi ve sağlık bakımına yönelik bilgiler, hemşirelik mesleğini dolayısı ile de hemşirelik eğitimini etkilemektedir. Hemşirelik eğitimi öğrencilerde sorumluluk, çözüm üretme, düşünme, yaratma ve duyarlılık gibi faktörlerin kazanılmasını hedeflemektedir. Tüm bunların yanında öğrencilerin bilişsel, duyuşsal ve psikomotor becerilere sahip olması ve çevresiyle etkileşim içinde bütüncül yaklaşım sergilemesi hemşirelik eğitiminin temel hedefleri arasındadır. $\mathrm{Bu}$ doğrultuda hemşirelik eğitiminde öğrenmeyi öğrenme ve doğru öğrenme stratejilerinin seçilmesi bir zorunluluktur (Çakmak, Akgün, Karadeniz, Büyüköztürk, \&Demirel, 2008; Garcia \& Pintrich, 1995; Gopee, 2002; Kaya ve Akçin, 2002; Pintrich, Smith, Garcia, \& McKeachie, 1991; Şenyuva, 2013; Titmus, 1999).

Öğrenmeyi öğrenme, öğrenenin öğrenme sorumluluğunu üstlenmesidir. Öğrenme sorumluluğunu üstlenebilmek için 'öğrenme' konusunda bilgi ve beceriye sahip olunması ve bireysel öğrenme biçiminin çok iyi tanınması gerekmektedir (Erdem, 2005). Öğrencilerin öğrenme sürecinde sorumluluk almaları ve etkin rol üstlenmeleri için sürece katılmaya istekli yani güdülenmiş olmaları ve kendi öğrenme stratejilerinin farkında olmaları gerekir (Uyulgan \& Akkuzu, 2014). 
Gün, T., \& Denat, Y. (2020). Hemşirelik öğrencilerinin güdülenme ve öğrenme stratejileri. Journal of Human Sciences, 17(1), 32-48. doi:10.14687/jhs.v17i1.5784

Güdülenme bireylerin öğrenmesini etkileyen temel faktörlerden biridir (Kelecioğlu, 1992). Ĕ̆itim öğretim süreci boyunca, öğretim faaliyetlerinin hedeflerine ulaşabilmesi, bireyin ilgi duyduğu o konuyu öğrenmek istemesi yani güdülenmiş olması ile mümkündür (Uyulgan \& Akkuzu, 2014). Sarmasoğlu ve Görgülü (2014) tarafindan yapılan araştırmada; öğrencilerin, Kendi Kendine Öğrenmeye Hazıroluş (KKÖH) düzeyleri incelemiş ve yarısından fazlasının (\%76.6) KKÖH düzeylerinin yeterli olduğu belirlenmiştir. El-Gilany ve Abusaad (2013) yaptıkları çalışmada; öğrencilerin \% 77'sinin, Yuan, Wiliams, Fang ve Pang (2012) yaptıkları çalışmada, öğrencilerin \% 62.3'ünün $\mathrm{KKÖH}$ düzeylerinin yeterli olduğu belirlenmiştir. Smedley (2007) 'in birinci sinıf hemşirelik öğrencilerinde yaptığı çalışmada, öğrencilerin KKÖH düzeylerinin diğer sınıflara göre daha yetersiz olduğu belirlenmiştir. Espeland ve Indrehus'un (2003) yaptığ1 çalışmada hemşirelik öğrencilerinin güdülenme düzeyinin üniversitenin diğer bölümlerindeki öğrencilerden daha düşük olduğu belirtilmektedir (Acat \& Kösgeroğlu, 2006; Espeland \& Indrehus, 2003).

Bireyin öğrenmesini etkileyen temel faktörlerden bir diğeri de öğrenme stratejisidir. Öğrenme stratejisi, genel olarak bireyin öğrenirken izlediği yoldur (Yavuzalp, 2012). Yapılan çalışmalarda, öğrenim gören öğrencilerin eğitim sürecinde başarısızlı̆̆ın nedeni olarak öğrenme stili ve stratejisi ile uyum göstermeyen bir eğitim sistemi olduğu, buna karşın öğrenme stratejilerinin öğrencinin not ortalamalarında ve mezuniyet sonrası iş yaşantısında etkili olduğu bildirilmektedir (Veznedaroğlu \& Özgür, 2005; Cesur, 2008; Çelik vd., 2014b). Bu konuya ilişkin araştırmalardan ortaya çıkan sonuç; başarılı öğrencilerin öğrenme stratejilerini etkili kullanırken, başarısız öğrencilerin ise öğrenme stratejilerini etkili kullanmada zorluklar yaşadıkları yönündedir (Deryakulu, 2004). Başarılı bireyler, özel öğrenme durumları için kendilerine uygun olan öğrenme stratejilerini seçebilen ve bunları esnek bir şekilde farklı öğrenme durumlanına uyarlayabilen bireylerdir. Bu bireyler kendi öğrenme stillerinin ve ne yaptıklarının farkındadırlar (Yavuzalp, 2012). Literatürde farklı öğrenme stratejilerini etkili bir şekilde bir arada kullanan ve yeni stratejiler oluşturabilen öğrencilerin, özdüzenlemeli bir öğrenmeyi gerçekleştirmede başarılı oldukları belirtilmektedir (Özer, 1998; Çakmak, vd., 2008). Şenyuva (2009) hemşirelik bölümü öğrencilerinin sırasıyla en fazla ayrıştıran, özümseyen, değiştiren ve en az da yerleştiren öğrenme stilin kullandıklarını saptamıştır. Çelik vd. (2014b) tarafindan yapılan bir diğer çalışmada da hemşirelik öğrencilerinin yoğun olarak ayrıştıran ve yerleştiren öğrenme stilini kullandıkları belirlenmiştir. Yapılan pek çok çalışmada öğrencilerin çoğunun ayrıştıran ve özümseyen öğrenme stilini kullandıkları belirlenmiştir (Dikmen, 2015; Güllerci \& Oflaz, 2010; Özen, 2011; Seven, Bağcivan, Kılıç, \& Açıkel, 2012; Şenyuva, 2009). Çelik vd. (2014b)'nın yaptı̆̆ çalışmada ise hemşirelik öğrencilerinin öğrenme stratejilerinden en çok dikkat stratejisini, en az olarak da duyuşsal strateji kullanmayı tercih ettikleri belirlenmiştir. Karakış (2006)'in yaptığı araştırmada üniversite öğrencilerinin, çoğunlukla dikkat stratejisi, en az da duyuşsal strateji kullanmaya başvurdukları saptanmıştır.

Araştırmalar bireylerin akademik yaşantıları boyunca başarllı olabilmelerinde güdülenme ve uygun öğrenme stratejilerini kullanabilmelerinin anahtar rol oynadığını göstermektedir (Çakmak vd., 2008; Garcia \& Pintrich, 1995). Literatürde hemşirelik öğrencilerinin öğrenme sürecinde hem güdülenme tür ve düzeylerine hem de öğrenme stratejilerinin değerlendirilmesine ilişkin sinırlı sayıda çalışma yer almakta olup (Çelik, Şahin, Dadak, Sıdal, \& Akyüz, 2014a; Çelik vd., 2014b; Güven \& Kurum 2006; Kaya \& Akçin 2002) çalışmaların genellikle öğrencilerin öğrenme stillerine yönelik olduğu görülmektedir. Bu doğrultuda hemşirelik öğrencilerinin güdülenme kaynaklarını ve kullandıkları ögrrenme stratejilerini belirlenmek önemli bir gerekliliktir. Öğrencilerin sınıf düzeylerine göre, hangi stratejiyi etkili olarak kullandıklarının, güdülenme tür ve düzeylerinin incelenmesi, ayrıca bunları etkileyen etmenlerin belirlenmesi hemşirelik eğitiminin niteliğinin artmasına katk1 sağlayacaktır. Bu araştırma sonuçları ile eğitimcilerin, öğrencilerin bireysel farklılıkları göz önünde bulundurarak, öz düzenlemeli öğrenme ortamlarını oluşturmalarında, öğrencilerin ise nasıl öğrendiklerinin farkına vararak kendi öğrenme süreçlerini düzenlemelerinde, öğrenme başarısı ve motivasyonu artırmada ve yaşam boyu öğrenmeyi amaç edinmiş kaliteli bir eğitim sağlamada yol gösterici olacağ1 düşünülmektedir. 
Gün, T., \& Denat, Y. (2020). Hemşirelik öğrencilerinin güdülenme ve öğrenme stratejileri. Journal of Human Sciences, 17(1), 32-48. doi:10.14687/jhs.v17i1.5784

\section{Amaç}

$\mathrm{Bu}$ araştırmada amaç, hemşirelik öğrencilerinin güdülenme ve öğrenme stratejileri ile etkileyen etmenleri belirlemektir.

\section{Yöntem}

\subsection{Araştırmanın Tipi}

Bu araştırma tanımlayıcı ve analitik bir çalışmadır.

\subsection{Araştırmanın Evreni ve Örneklemi}

Araşturmanın evrenini 2015-2016 öğretim yllında Türkiye'nin batısındaki bir Sağlık Yüksekokulu Hemşirelik Bölümü'ndeki öğrenciler oluşturmaktadır. Araştırmada evrenin tümüne ulaşılması amaçlanmışır. Araştırmanın örneklemini 01 Mart-31 Mayıs 2016 tarihleri arasında (3 ay) Türkiye'nin batısındaki bir Sağlık Yüksekokulu Hemşirelik Bölümü’nde öğrenim görmekte olan 849 öğrenciden araştırmaya katılmaya gönüllü olan, araştırmanın verileri toplanırken devamsızlık yapmamış olan ve veri toplama formunu eksiksiz olarak tamamlayan toplam 648 hemşirelik bölümü öğrencisi oluşturmuştur. Evrenin \%76'sına ulaşılmıştır. Tablo 1'de araştırmaya katılan öğrencilerin sınıf dağglımları sunulmuştur.

Tablo 1. Öğrencilerin Sınıflara Göre Dağılımı

\begin{tabular}{lcc}
\hline Sinıf & $\mathbf{N}$ & $\mathbf{\%}$ \\
1. Sinıf & 135 & 20.8 \\
2. Sinif & 197 & 30.4 \\
3. Sinıf & 232 & 35.8 \\
4. Sinif & 84 & 13.0 \\
\hline Toplam & $\mathbf{6 4 8}$ & $\mathbf{1 0 0}$
\end{tabular}

Örneklem büyüklüğ̈nün gücünü belirlemek amacı ile power analizi yapılmıştır.0.05 $\alpha$ katsayıs1 (yanılma payı) ve 0.99 güç ile 648 örnekleme ulaşılmıştır.

\subsection{Veri Toplama Araçları}

Araştırma verileri, "Bilgi Formu" ve "Güdülenme ve Öğrenme Stratejileri Ölçeği” ile toplanmıştır. Bilgi Formu; öğrencilere ilişkin tanıtıcı bilgiler ile öğrencilerin güdülenme ve öğrenme stratejilerini etkileyebileceği düşünülen faktörlere ilişkin literatür doğrultusunda hazırlanan toplam 5 sorudan oluşmaktadır (Çelik vd., 2014a; Çelik vd., 2014b; Güllerci \& Oflaz, 2010, Higgins \& Kruglanski, 2000; Yenice, Saydam, \& Telli, 2012). Güdülenme ve ögrrenme stratejileri ölçeği (GÖSÖ): Pintrich vd. (1991)'nin geliştirdiği, Büyüköztürk, Akgün, Özkahveci, Demirel (2004)'in üniversite öğrencilerinde Türkçe geçerlik ve güvenirliğini yaptığı orijinal ismi "Motivated Strategies for Learning Questionnaire (MSLQ)" olan Likert tipi bir ölçektir. Ölçek temelde "Güdülenme Ölçeği” ve "Öğrenme Stratejileri Ölçeği” olmak üzere iki bölümden oluşmaktadır. GÖSÖ, iki ana bölümde 15 alt faktörden oluşan, modüler bir ölçektir. Kullanım amacına göre ölçek alt faktörlerden alınan puanlar ile ayrı olarak da kullanılabilmektedir. Katılımcılar ölçekteki her bir maddeyi "benim için kesinlikle yanlış" (1) ile "benim için kesinlikle doğru" (7) arasında Likert türü yedili bir derecelendirme üzerinde işaretlemektedirler (Büyüköztürk vd., 2004; Pintrich, Smith, Garcia, Mckeachie, 1993). Ölçeğin faktörlerinden herhangi birinden elde edilen yüksek puan, öğrencinin o faktöre yönelik özelliğe yüksek düzeyde sahip olduğunu göstermektedir. Ölçek 20-30 dakikada uygulanmaktadır. Güdülenme ve Öğrenme stratejileri ölçeğinin, Güdülenme Boyutunun Kurumsal Alt Yapısı Tablo 2'de ve Öğrenme Stratejileri Boyutunun Kurumsal Alt Yapısı Tablo 3’te sunulmuştur. 
Gün, T., \& Denat, Y. (2020). Hemşirelik öğrencilerinin güdülenme ve öğrenme stratejileri. Journal of Human Sciences, 17(1), 32-48. doi:10.14687/jhs.v17i1.5784

Faktörlerin Cronbach alfa katsayıları 0.86 ile 0.41 arasında değişmektedir (Büyüköztürk vd, 2004). Bu çalışmada ise Cronbach alfa katsayıları 0.87 ile 0.61 arasında değşmektedir.

*Tablo 2. Güdülenme ve Öğrenme Stratejileri Ölçeği (GÖSÖ) Güdülenme Boyutu Kuramsal Alt Yap1s1

\begin{tabular}{|c|c|c|}
\hline Ana Bileşen & Faktör & Açılklama \\
\hline Değer (Value) & $\begin{array}{l}\text { - İçsel Hedef Düzenleme } \\
\text { - Dişsal Hedef Düzenleme } \\
\text { - Görev Değeri }\end{array}$ & $\begin{array}{l}\text { - Öğrenen bireylerin hedef ve görevlerinin } \\
\text { önemine ilişkin inançları ve ilgileri }\end{array}$ \\
\hline Beklenti (Expectancy) & $\begin{array}{l}\text { - Öz Yeterlik Alg1sı } \\
\text { - Öğrenme Kontrolü İnanc1 }\end{array}$ & $\begin{array}{l}\text { - Öğrenen bireylerin performanslarına ilişkin } \\
\text { alg1 ve inançları }\end{array}$ \\
\hline Duyuşsal (Affective) & - Sinav Kaygisı & $\begin{array}{l}\text { - Öğrenen bireylerin bir göreve yönelik } \\
\text { duyuşsal tepkileri }\end{array}$ \\
\hline
\end{tabular}

*Büyüköztürk vd. (2004)'den izin alınarak kullanılmıştır.

*Tablo 3. Güdülenme ve Öğrenme Stratejileri Ölçeği (GÖSÖ) Öğrenme Stratejileri Boyutu Kuramsal Alt Yapis1

\begin{tabular}{|c|c|c|}
\hline Ana Bileşen & Faktör & Açılklama \\
\hline \multirow{4}{*}{$\begin{array}{l}\text { Bilişsel } \\
\text { Stratejiler }\end{array}$} & $\begin{array}{l}\text { - Yineleme } \\
\text { Stratejiler }\end{array}$ & $\begin{array}{l}\text { - Öğrenci öğrenilecek konuyu hatırlamak için zihinsel tekrarlamalar yaparak } \\
\text { öğrenir. Amaç ezberleyerek öğrenmedir. } \\
\text { - Bütünüyle hatırlanması beklenen konuların öğrenilmesinde kullanılır. }\end{array}$ \\
\hline & $\begin{array}{l}\text { - Açımlama } \\
\text { Stratejileri }\end{array}$ & $\begin{array}{l}\text { - Bu stratejilerle öğrenciler yeni ögrendiği bilgileri öncekilerle birleştirerek } \\
\text { sentezlediği bilgileri uzun süreli hafızada tutmayı sağlar. } \\
\text { - Notlar çıkarma, yorum yapma, özet çıkarma, benzetim yaratma vb. }\end{array}$ \\
\hline & $\begin{array}{l}\text { - Düzenleme } \\
\text { Stratejileri }\end{array}$ & $\begin{array}{l}\text { - Öğrenciler bu stretejilerle uygun bilgileri seçerek, öğrenilenecek bilgiler } \\
\text { arasıda bağlantılar kurarak bilginin yapılanmasını sağlar. } \\
\text { - Gruplama/sınıflandırma, ana fikri belirleme, konunun ana hatlarını } \\
\text { çıartma vb. }\end{array}$ \\
\hline & $\begin{array}{l}\text { - Eleştirel Düşüme } \\
\text { Stratejileri }\end{array}$ & $\begin{array}{l}\text {-Bu stratejiyi kullanan öğrenci yeni karşılaştığı herhangi bir problemi, eski } \\
\text { bilgilerinden hangisinin kullanacağına karar vererek problemi çözer ve } \\
\text { eleştirel değerlendirme yapma. }\end{array}$ \\
\hline \multirow{3}{*}{$\begin{array}{l}\text { Metabilişsel } \\
\text { Stratejiler }\end{array}$} & - Planlama & - Hedef belirleme, görev analizi yapma vb. \\
\hline & • İzleme & $\begin{array}{l}\text { - Okunan konuyu dikkatli bir şekilde devam ettirme, kendi kendine sorular } \\
\text { çıartarak, öz denetim yapma. }\end{array}$ \\
\hline & - Düzenleme & $\begin{array}{l}\text { - Öğrenme performansını geliştirmek için davranışların kontrol edilmesi ve } \\
\text { düzeltilmesi. }\end{array}$ \\
\hline \multirow{4}{*}{$\begin{array}{l}\text { Kaynak } \\
\text { Yönetimi }\end{array}$} & $\begin{array}{l}\text { - Zaman ve } \\
\text { Çalışma Ortamı } \\
\text { Yönetimi }\end{array}$ & $\begin{array}{l}\text {-Günlük, haftalık, aylık ve yıllık program yaparak zaman yönetimi sağlanır. } \\
\text { Uzun ve kısa vadeli amaçlar belirlenip, plan yaparak çalışma zamanı etkin } \\
\text { kullanılır. } \\
\text {-Çalışma ortamı, öğrencinin dikkatini dağıtan uyaranlardan uzak olup, } \\
\text { öğrenebileceği ortamı yaratarak düzenleme yapmasıdır. }\end{array}$ \\
\hline & • Emek Yönetimi & $\begin{array}{l}\text { - öğrencinin karşılaştığ zor görev ve konularda, başarılı olma vb. amaçlarına } \\
\text { bağlı kalarak o göreve/konuya dikkatini vermesi ve çalışma çabasını } \\
\text { devam ettirmesi. }\end{array}$ \\
\hline & $\begin{array}{l}\text { - Akran İşbirliği } \\
\text { Yönetimi }\end{array}$ & $\begin{array}{l}\text { - Öğrencinin öğrenmesini kolaylaştırmak için ekip çalışmalarından } \\
\text { yararlanarak arkadaşlarıyla ortak amaç içinde olmasıdır. }\end{array}$ \\
\hline & - Yardım isteme & $\begin{array}{l}\text { - Öğrencinin gerektiğinde arkadaşlarından veya uzman kişilerden yardım } \\
\text { istemesidir. Burada önemli olan yardıma ihtiyacı olduğunu fark edip, } \\
\text { doğru kişilere başvurmaktır. }\end{array}$ \\
\hline
\end{tabular}

*Büyüköztürk vd. (2004)'den izin alınarak kullanılmıştır. 
Gün, T., \& Denat, Y. (2020). Hemşirelik öğrencilerinin güdülenme ve öğrenme stratejileri. Journal of Human Sciences, 17(1), 32-48. doi:10.14687/jhs.v17i1.5784

\subsection{Verilerin Toplanmas1}

Araşturmada, öğrencilere araştırmaya ilişkin bilgi verilmiş ve araştırmaya katılmaya istekli öğrencilerden sözel onay alınmıştr. Veri toplama formları ("Bilgi Formu" ve "Güdülenme ve Öğrenme Stratejileri Ölçeği”) öğrencilere dağitılarak öğrencilerin doldurulması istenmiştir. Veriler özellikle devamsızlı̆̆n daha az olduğu derslerin sonunda toplanmıştır. Bir öğrencinin veri toplama formalarını doldurması yaklaşı 20-30 dakika sürmüştür.

\subsection{Verilerin Değerlendirilmesi}

Verilerin analizinde SPSS (Statistical Package for Social Sciens) for Windows 20.0 paket programı kullanılmıştur. Çalışmanın istatistiksel analizinde gruplar ile güdülenme ve öğrenme stratejilerin alt kategorilerinin karşılaştırılması için öncelikle Kolmogorov-Smirnov testi ile normallikleri incelenmiştir. Normal dağglım göstermeyen $(\mathrm{p}<0.05)$ değişkenlerin gruplardaki karşılaştırılması için grupların kategori sayısı iki olanlar için Mann-Whitney U test istatistiği; grupların kategori sayısı ikiden fazla olduğu durumda ise Kruskal Wallis test istatistiği kullanılmıştır. Normal dağılıma sahip iki kategorili gruplar bulunmamaktadır. Normal dağılıma sahip grup kategori sayısı ikiden fazla olan grupları karşılaştırmak için ise Tek Yönlü Varyans testi kullanılmıştır. Yaş değişkeni ile güdülenme ve öğrenme stratejilerinin alt kategorileri arasındaki ilişkinin incelenmesinde Spearman test istatistiğinden yararlanılmıştır. Gruplarda farklı çıkan güdülenme ve öğrenme stratejilerinin alt gruplar değişkenlerinin hangi gruplarda farklı çıktı̆ını öğrenmek için Tek yönlü varyans analizi uygulanan değişken için Tamhane testi; Kruskal Wallis analizi uygulanan değişkenler için çoklu karşılaştırma testi (pairwise comparisons) uygulanmıştır.

Sonuçlar için $\mathrm{p}<0.05$ için istatistiksel olarak anlamlı kabul edilmiştir.

\subsection{Araştırmanın Etik Yönü}

Araştırmanın yürütülmesi için Adnan Menderes Üniversitesi Tıp Fakültesi Girişimsel Olmayan Araştırmalar Etik Kurulu'ndan onay (onay no: 53043469-050.04.04), Adnan Menderes Üniversitesi Aydın Sağlık Yüksekokulu Müdürlügüu’nden araştırma izini alınmıştır. Öğrencilerin sözlü onamları alınmıştır.

\section{Bulgular}

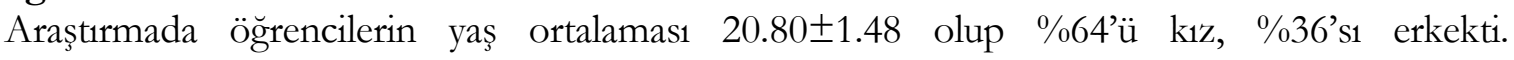
Araştırmaya katılan öğrencilerin \%20.8’inin 1. sınıf, \%30.4'sının 2. sınıf, \%35.8’inin 3. sinıf ve \%13'ünün ise 4. sinıfta olduğu belirlendi. Araştırmaya katılan öğrencilerin \%38.1'inin hemşirelik mesleğini isteyerek seçtĭgi, \%28.1'inin mesleği isteyerek seçmediği, \%33.8'inin ise hemşirelik mesleğini kısmen isteyerek seçtiği belirlendi. Araştırma kapsamına alınan öğrencilerin \%42.9'unun düzenli olarak kitap okuduğu, \%57.1’inin düzenli kitap okumadığı belirlendi

\section{1.Öğrencilerin Güdülenme Durumlarını Etkileyen Etmenlere İlişkin Bulgular}

Öğrencilerin güdülenmeye ilişkin alt faktör puan ortalamaları; içsel hedef $4.82 \pm 1.14$, dişsal

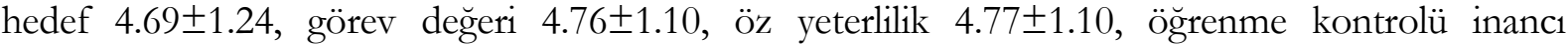
$4.80 \pm 1.06$, sinav kayg1si $4.31 \pm 1.19$ olarak belirlendi. 
Gün, T., \& Denat, Y. (2020). Hemşirelik öğrencilerinin güdülenme ve öğrenme stratejileri. Journal of Human Sciences, 17(1), 32-48. doi:10.14687/jhs.v17i1.5784

Tablo 4. Öğrencilerin Bazı Değişkenlere Göre Güdülenme Alt Faktör Puan Ortalamalarının Karşılaşturilması (n:648)

\begin{tabular}{|c|c|c|c|c|c|c|c|c|c|c|c|c|c|}
\hline \multirow{4}{*}{ Değişkenler } & \multirow{4}{*}{$\mathbf{N}$} & \multicolumn{12}{|c|}{ Güdülenme Alt Faktörleri } \\
\hline & & \multicolumn{6}{|c|}{ Değer } & \multicolumn{4}{|c|}{ Beklenti } & \multicolumn{2}{|c|}{ Duyuşsal } \\
\hline & & \multicolumn{2}{|c|}{ İçsel Hedef } & \multicolumn{2}{|c|}{ Dişsal Hedef } & \multicolumn{2}{|c|}{ Görev Değeri } & \multicolumn{2}{|c|}{$\begin{array}{c}\text { Öz Yeterlilik } \\
\text { Alg1sı }\end{array}$} & \multicolumn{2}{|c|}{$\begin{array}{c}\text { Öğrenme } \\
\text { Kontrolü } \\
\text { İnancı }\end{array}$} & \multicolumn{2}{|c|}{ Sinav Kayg1s } \\
\hline & & $\overline{\mathbf{X}}$ & SS & $\overline{\mathbf{X}}$ & SS & $\overline{\mathbf{X}}$ & SS & $\overline{\mathbf{X}}$ & SS & $\overline{\mathbf{X}}$ & SS & $\overline{\mathbf{X}}$ & SS \\
\hline \multicolumn{14}{|l|}{ Cinsiyet } \\
\hline$K_{1 z}$ & 415 & 4.89 & 1.10 & 4.71 & 1.23 & 4.86 & 1.05 & 4.85 & 1.11 & 4.74 & 1.03 & 4.42 & 1.22 \\
\hline Erkek & 233 & 4.68 & 1.18 & 4.64 & 1.26 & 4.59 & 1.16 & 4.72 & 1.09 & 4.91 & 1.11 & 4.11 & 1.12 \\
\hline$* \mathrm{Z} / \mathrm{p}$ & & \multicolumn{2}{|c|}{$\mathrm{Z}=-2.122$} & \multicolumn{2}{|c|}{$Z=-0.623$} & \multicolumn{2}{|c|}{$Z=-2.868$} & \multicolumn{2}{|c|}{$Z=-1.288$} & \multicolumn{2}{|c|}{$Z=-2.165$} & \multicolumn{2}{|c|}{$\mathrm{Z}=-3.610$} \\
\hline & & \multicolumn{2}{|c|}{$\mathrm{p}=0.034$} & \multicolumn{2}{|c|}{$\mathrm{p}=0.534$} & \multicolumn{2}{|c|}{$\mathrm{p}=0.004$} & \multicolumn{2}{|c|}{$\mathrm{p}=0.198$} & \multicolumn{2}{|c|}{$\mathrm{p}=\mathbf{0 . 0 3 0}$} & \multicolumn{2}{|c|}{$\mathrm{p}=0.001$} \\
\hline \multicolumn{14}{|c|}{ Öğrenim Görülen Sınıf } \\
\hline 1.Sinif & 135 & 4.99 & 1.23 & 4.96 & 1.28 & 4.92 & 1.19 & 5.14 & 1.15 & 4.95 & 1.17 & 4.29 & 1.19 \\
\hline 2.Sınıf & 197 & 4.86 & 1.16 & 4.68 & 1.25 & 4.78 & 1.12 & 4.77 & 1.20 & 4.78 & 1.04 & 4.30 & 1.14 \\
\hline 3.Sınıf & 232 & 4.76 & 1.09 & 4.59 & 1.22 & 4.70 & 1.02 & 4.64 & 0.99 & 4.76 & 0.99 & 4.32 & 1.25 \\
\hline 4.Sınıf & 84 & 4.63 & 1.05 & 4.54 & 1.18 & 4.63 & 1.10 & 4.55 & 0.91 & 4.69 & 1.10 & 4.34 & 1.16 \\
\hline \multirow[t]{2}{*}{$* * \mathrm{~F} / \mathrm{p}$} & & \multicolumn{2}{|c|}{$F=8.699$} & \multicolumn{2}{|c|}{$F=8.928$} & \multicolumn{2}{|c|}{$\mathrm{F}=5.954$} & & & $\mathrm{~F}=$ & 872 & $\mathrm{~F}=$ & \\
\hline & & $\mathrm{p}=$ & & $\mathrm{p}=$ & & & & & & $\mathrm{p}=\mathrm{c}$ & & $\mathrm{p}=$ & \\
\hline Mesleği İst & erek & çme & Duru & & & & & & & & & & \\
\hline Evet & 247 & 4.82 & 1.10 & 4.57 & 1.29 & 4.94 & 1.13 & 4.89 & 1.12 & 4.76 & 1.08 & 4.48 & 1.26 \\
\hline Hayır & 182 & 4.71 & 1.15 & 4.75 & 1.20 & 4.47 & 1.08 & 4.61 & 1.07 & 4.77 & 1.17 & 4.10 & 1.12 \\
\hline Kismen evet & 219 & 4.91 & 1.17 & 4.77 & 1.21 & 4.81 & 1.03 & 4.77 & 1.09 & 4.87 & 0.94 & 4.29 & 1.14 \\
\hline$* * * \chi^{2} / \mathrm{p}$ & & $\begin{array}{l}\chi^{2}= \\
\mathrm{p}=\end{array}$ & & $\begin{array}{l}\chi^{2}= \\
\mathrm{p}=\end{array}$ & & $\chi^{2}=$ & .645 & $\chi^{2}$ & & $\begin{array}{l}\chi^{2}= \\
p=\end{array}$ & & $\begin{array}{r}\chi^{2}= \\
\mathrm{p}=\end{array}$ & $\begin{array}{l}163 \\
04\end{array}$ \\
\hline Düzenli Kit & Ok & a D & tim & & & & & & & & & & \\
\hline Evet & 278 & 4.97 & 1.11 & 4.73 & 1.29 & 4.84 & 1.07 & 4.94 & 1.08 & 4.88 & 1.08 & 4.28 & 1.17 \\
\hline Hayır & 370 & 4.71 & 1.15 & 4.66 & 1.20 & 4.71 & 1.12 & 4.65 & 1.10 & 4.73 & 1.05 & 4.33 & 1.21 \\
\hline$* \mathrm{Z} / \mathrm{p}$ & & $\begin{array}{l}\mathrm{Z}= \\
\mathrm{p}=\end{array}$ & & $\begin{array}{l}\mathrm{Z}= \\
\mathrm{p}=\end{array}$ & & & $\begin{array}{l}917 \\
55 \\
\end{array}$ & $\begin{array}{l}\mathrm{Z}= \\
\mathrm{p}=\end{array}$ & & $\begin{array}{l}\mathrm{Z}= \\
\mathrm{p}=\end{array}$ & & $\begin{array}{l}\mathrm{Z}= \\
\mathrm{p}=\end{array}$ & \\
\hline
\end{tabular}

*Mann-Whitney U testi, **Tek Yönlü Varyans Analizi, *** Kruskal Wallis Analizi

Araştırmada kız öğrencilerin içsel hedef, görev değeri ve sınav kaygısı, erkek öğrencilerin ise öğrenme kontrolü inancı puan ortalamaları anlamlı derecede yüksek bulundu $(\mathrm{p}<0.05)$. 1. sinıfların içsel ve dışsal hedef puan ortalamalarının 3. ve 4. sınıflara göre, öz yeterlilik puan ortalamalarının ise 2. 3. ve 4. sinıflara göre anlamlı düzeyde daha yüksek olduğu saptandı. Hemşirelik mesleğini isteyerek ve kısmen isteyerek seçen öğrencilerin görev değeri, hemşirelik mesleğini isteyenlerin ise ayrıca öz yeterlilik ve sınav kaygısı, düzenli kitap okuyanların içsel hedef ve öz yeterlilik puan ortalamalarının anlamlı olarak yüksek olduğu saptandı $(\mathrm{p}<0.05)$ (Tablo 4).

\section{2. Öğrencilerin Öğrenme Stratejilerini Etkileyen Etmenlere İlişkin Bulgular}

Öğrencilerin öğrenme stratejileri alt faktör puan ortalamaları; yineleme 4.68 11.12 , açımlama $3.91 \pm 0.98$, düzenleme $4.73 \pm 1.16$, eleştirel düşünme $4.58 \pm 1.05$, metabilişsel stratejileri $4.59 \pm 0.88$, zaman ve çalışma ortamı $4.36 \pm 0.79$, emek $4.30 \pm 0.84$, akran işbirliği yönetimi $3.91 \pm 1.28$ ve yardım isteme stratejisi $4.03 \pm 1.04$ olarak belirlendi. 
Tablo 5. Öğrencilerin Bazı Değișkenlere Göre Öğrenme Stratejilerinin Alt Faktör Puan Ortalamalarının Karșılaștırılması (n:648)

\begin{tabular}{|c|c|c|c|c|c|c|c|c|c|c|c|c|c|c|c|c|c|c|c|}
\hline \multirow{4}{*}{ Değişkenler } & \multirow[b]{4}{*}{$\mathbf{N}$} & \multicolumn{18}{|c|}{ Öğrenme Stratejisi } \\
\hline & & \multicolumn{8}{|c|}{ Bilişsel } & \multirow{2}{*}{\multicolumn{2}{|c|}{$\begin{array}{c}\text { Metabilişsel } \\
\text { Metabilişsel } \\
\text { Stratejiler }\end{array}$}} & \multicolumn{8}{|c|}{ Kaynak Yönetimi } \\
\hline & & \multicolumn{2}{|c|}{ Yineleme } & \multicolumn{2}{|c|}{ Açımlama } & \multicolumn{2}{|c|}{ Düzenleme } & \multicolumn{2}{|c|}{$\begin{array}{c}\text { Eleştirel } \\
\text { Düşünme }\end{array}$} & & & \multicolumn{2}{|c|}{$\begin{array}{c}\text { Zaman ve } \\
\text { Çalışma } \\
\text { Ortamı }\end{array}$} & \multicolumn{2}{|c|}{$\begin{array}{c}\text { Emek } \\
\text { Yönetimi }\end{array}$} & \multicolumn{2}{|c|}{$\begin{array}{c}\text { Akran } \\
\text { İşbirliği }\end{array}$} & \multicolumn{2}{|c|}{$\begin{array}{l}\text { Yardım } \\
\text { İsteme }\end{array}$} \\
\hline & & $\overline{\mathbf{x}}$ & SS & $\overline{\mathbf{x}}$ & SS & $\overline{\mathbf{x}}$ & SS & $\overline{\mathbf{x}}$ & SS & $\overline{\mathbf{X}}$ & SS & $\overline{\mathbf{x}}$ & SS & $\overline{\mathbf{x}}$ & SS & $\overline{\mathbf{x}}$ & SS & $\overline{\mathbf{x}}$ & SS \\
\hline \multicolumn{20}{|l|}{ Cinsiyet } \\
\hline $\mathbf{K} \mathbf{z}$ & 415 & 4.74 & 1.23 & 4.01 & 0.95 & 4.83 & 1.16 & 4.62 & 1.02 & 4.67 & 0.90 & 4.43 & 0.82 & 4.33 & 0.79 & 3.80 & 1.22 & 4.03 & 1.02 \\
\hline Erkek & 233 & 4.56 & 1.11 & 3.73 & 1.02 & 4.54 & 1.14 & 4.52 & 1.11 & 4.44 & 0.83 & 4.24 & 0.71 & 4.24 & 0.93 & 4.11 & 1.36 & 4.03 & 1.08 \\
\hline$* \mathrm{Z} / \mathrm{l}$ & & \multicolumn{2}{|c|}{$\begin{array}{l}\mathrm{Z}=-1.799 \\
\mathrm{p}=0.072\end{array}$} & \multicolumn{2}{|c|}{$\begin{array}{c}\mathrm{Z}=-3.362 \\
\mathrm{p}=\mathbf{0 . 0 0 1}\end{array}$} & \multicolumn{2}{|c|}{$\begin{array}{c}\mathrm{Z}=-2.976 \\
\mathrm{p}=\mathbf{0 . 0 0 3}\end{array}$} & \multicolumn{2}{|c|}{$\begin{aligned} Z & =-1.152 \\
p & =0.249\end{aligned}$} & \multicolumn{2}{|c|}{$\begin{array}{c}\mathrm{Z}=-2.774 \\
\mathrm{p}=\mathbf{0 . 0 0 6}\end{array}$} & \multicolumn{2}{|c|}{$\begin{array}{l}\mathrm{Z}=-2.178 \\
\mathrm{p}=0.029\end{array}$} & \multicolumn{2}{|c|}{$\begin{array}{c}\mathrm{Z}=-0.947 \\
\mathrm{p}=0.344\end{array}$} & \multicolumn{2}{|c|}{$\begin{array}{c}\mathrm{Z}=-2.815 \\
\mathrm{p}=0.005\end{array}$} & \multicolumn{2}{|c|}{$\begin{array}{l}Z=-0.386 \\
p=0.699\end{array}$} \\
\hline \multicolumn{20}{|c|}{ Hemşirelik Mesleğini İsteyerek Seçme Durumu } \\
\hline Evet & 247 & $4.75^{\circ}$ & 1.11 & 4.05 & 0.93 & 4.86 & 1.11 & 4.64 & 1.04 & 4.68 & 0.90 & 4.47 & 0.82 & 4.38 & 0.84 & 3.95 & 1.29 & 4.13 & 1.07 \\
\hline Hayır & 182 & 4.47 & 1.11 & 3.64 & 1.02 & 4.47 & 1.11 & 4.36 & 1.05 & 4.40 & 0.89 & 4.18 & 0.73 & 4.17 & 0.93 & 3.88 & 1.36 & 3.78 & 1.00 \\
\hline Kismen & 219 & 4.76 & 1.13 & 3.96 & 0.96 & 4.80 & 1.22 & 4.69 & 1.05 & 4.64 & 0.82 & 4.38 & 0.77 & 4.32 & 0.75 & 3.90 & 1.99 & 4.13 & 1.01 \\
\hline$* * *$ & & \multicolumn{2}{|c|}{$\begin{array}{c}\chi^{2}=5.233 \\
p=0.073\end{array}$} & \multicolumn{2}{|c|}{$\begin{array}{c}\chi^{2}=14.599 \\
p=0.001\end{array}$} & \multicolumn{2}{|c|}{$\begin{array}{c}\chi^{2}=11.253 \\
p=0.004\end{array}$} & $\begin{array}{r}\chi^{2}= \\
p=0\end{array}$ & $\begin{array}{l}7.775 \\
020 \\
\end{array}$ & & \begin{tabular}{|l}
.705 \\
021
\end{tabular} & $\begin{array}{r}\chi^{2}= \\
p=\end{array}$ & & & $\begin{array}{l}4.180 \\
.124\end{array}$ & $\begin{array}{l}\chi^{2}= \\
p=\end{array}$ & $\begin{array}{l}.308 \\
520 \\
\end{array}$ & $\begin{array}{c}\chi^{2}= \\
p=c\end{array}$ & 003 \\
\hline Hemşirelik & itimir & en Mer & uniye & Düzeyi & & & & & & & & & & & & & & & \\
\hline Memnun & 192 & 4.94 & 1.13 & 4.19 & 1.01 & 4.99 & 1.20 & 4.84 & 1.13 & 4.88 & 0.96 & 4.54 & 0.89 & 4.47 & 0.88 & 4.00 & 1.30 & 4.24 & 0.97 \\
\hline $\begin{array}{l}\text { Kismen } \\
\text { Memnun }\end{array}$ & 354 & 4.66 & 1.02 & 3.89 & 0.89 & 4.74 & 1.05 & 4.56 & 0.94 & 4.54 & 0.73 & 4.36 & 0.71 & 4.31 & 0.75 & 3.91 & 1.23 & 3.96 & 1.07 \\
\hline $\begin{array}{l}\text { Memnun } \\
\text { Değil }\end{array}$ & 102 & 4.23 & 1.29 & 3.44 & 1.06 & 4.22 & 1.28 & 4.15 & 1.15 & 4.22 & 1.00 & 3.99 & 0.71 & 3.95 & 0.98 & 3.75 & 1.40 & 3.90 & 1.02 \\
\hline$* * * \chi$ & & $\begin{array}{r}\chi^{2}= \\
p=\end{array}$ & & $\begin{array}{r}\chi^{2}= \\
p=0\end{array}$ & $\begin{array}{l}7.105 \\
.001\end{array}$ & $\begin{array}{r}\chi^{2}= \\
p=0\end{array}$ & $\begin{array}{l}331 \\
01\end{array}$ & $\begin{array}{r}\chi^{2}=2 \\
p=0\end{array}$ & $\begin{array}{l}2.313 \\
001\end{array}$ & & $\begin{array}{l}5.507 \\
001\end{array}$ & $\begin{array}{r}\chi^{2}= \\
p=\end{array}$ & 54 & & $\begin{array}{l}25.057 \\
.001\end{array}$ & & $\begin{array}{l}.558 \\
169 \\
69\end{array}$ & $\begin{array}{c}\chi^{2}= \\
p=c\end{array}$ & $\begin{array}{l}1.853 \\
003\end{array}$ \\
\hline Düzenli & $\mathrm{Ol}$ & Durt & & & & & & & & & & & & & & & & & \\
\hline Evet & 415 & 4.77 & 1.16 & 4.02 & 1.06 & 4.86 & 1.22 & 4.67 & 1.12 & 4.78 & 0.94 & 4.45 & 0.87 & 4.32 & 0.84 & 3.95 & 1.32 & 4.10 & 1.02 \\
\hline Hayır & 233 & 4.60 & 1.09 & 3.82 & 0.91 & 4.63 & 1.10 & 4.51 & 0.99 & 4.44 & 0.80 & 4.29 & 0.71 & 4.28 & 0.85 & 3.89 & 1.25 & 3.98 & 1.06 \\
\hline$* \mathrm{Z} / \mathrm{p}$ & & $\begin{array}{l}\mathrm{Z}-2 \\
\mathrm{p}=\end{array}$ & & $\begin{array}{l}Z=- \\
p=0\end{array}$ & .002 & $\begin{array}{l}Z=- \\
p=0\end{array}$ & $\begin{array}{l}3.011 \\
.003\end{array}$ & $\begin{aligned} Z=-2 \\
p=0\end{aligned}$ & .0167 & & $\begin{array}{l}072 \\
001\end{array}$ & $\begin{array}{l}\mathrm{Z}= \\
\mathrm{p}=\end{array}$ & & & $\begin{array}{l}1.173 \\
.241\end{array}$ & & & $\begin{array}{l}Z=- \\
p=c\end{array}$ & \\
\hline
\end{tabular}

*Mann-Whitney U testi

*** Kruskal Wallis Analizi 
Gün, T., \& Denat, Y. (2020). Hemșirelik öğrencilerinin güdülenme ve öğrenme stratejileri. Journal of Human Sciences, 17(1), 32-48. doi:10.14687/jhs.v17i1.5784

Araştırmaya katılan kız öğrencilerin açımlama ve düzenleme, metabilişsel, zaman ve de çalışma ortamı yönetimi, erkek öğrencilerin ise akran ile işbirliği stratejileri anlamlı düzeyde yüksek bulundu. 1.sınıf öğrencilerinin açımlama ve eleştirel düşünme, metabilişsel, akran işbirliği yönetimi ve yardım isteme stratejileri, düzenli kitap okuyan öğrencilerin ise yineleme, açımlama, düzenleme, eleştirel düşünme ve metabilişsel stratejileri puan ortalamaları anlamlı düzeyde yüksek bulundu. Hemşirelik mesleğini istemeyerek seçen öğrencilerin açımlama, düzenleme, eleştirel düşünme ve yardım isteme stratejileri puan ortalamaları anlamlı düzeyde düşük saptandı $(\mathrm{p}<0.05)$ (Tablo 5).

\section{Tartışma}

Öğrenme sürecinde öğretim etkinliklerinin amaçlarına ulaşabilmesi, bireyin güdülenmiş olması ile mümkündür (Uyulgan \& Akkuzu, 2014). Hemşirelik öğrencilerinin güdülenme durumunu incelemek amacıyla yapılan bu araştırmada öğrencilerin en fazla "içsel hedef" daha sonra sırasıyla "öğrenme kontrolü inancı", “öz yeterlilik", "görev değeri”" ile "dışsal hedef” ve "sinav kaygısı" ile güdülendikleri görülmektedir. Cook, Thompson, \& Thomas (2011) MSLQ kullanarak tup öğrencilerinde yaptıkları çalışmada öğrencilerin öncelikle öz yeterlik ve öğrenme kontrolü inanc1 güdülenmelerini kullandıkları saptamışlardır. Bruso \& Stefaniak (2016) tarafından MSLQ ölçeği kullanarak üniversite öğrencileri üzerinde yapılan çalışmada ise, öğrencilerin en fazla "görev değeri”, daha sonra sırasıyla "öz yeterlilik", "içsel hedef”, "öğrenme kontrolü inancı", "dışsal hedef ve sınav kaygısı" ile güdülendikleri saptanmıştır. Çalışmada ilk üç sırada ve son iki sırada yer alan güdülenme şekilleri dikkate alındığında çalışma sonuçları bizim çalışma sonuçlarımızla benzer niteliktedir. Karataş, Güleş, \& Aypay (2014)'nın yaptığı çalışmada da benzer sonuçlar saptanmış olup bu çalışmada ilk üç sırada “dışsal hedef” ile güdülenmenin yer aldığ1 saptanmıştır. Bu farklıllğın örneklem grubunda farklı fakültelerin yer almasından kaynaklanmış olabileceği düşünülmektedir. Özkan, Akın, \& Durna (2015) hemşirelik öğrencilerinde motivasyon düzeylerini inceledikleri bir diğer çalışmada, "içsel güdülenme" düzeyinin "dışsal güdülenme"ye göre daha yüksek olduğu saptanmıştır. Görüldüğü gibi hemşirelik öğrencileri ve diğer üniversite öğrencileri öğrenmede daha çok “içsel hedef”, “öğrenme kontrolü”, “öz yeterlilik" ve "görev değeri” ile güdülenmektedir. Araştırmamız sonucunda öğrencilerin en az "sınav kaygıs"1 ile güdülendikleri saptanmış olup, literatürde yapılan çalışmalarda da "sınav kaygısının" güdülenmede en az etkili olduğu saptanmıştır (Bruso \& Stefaniak, 2016; Karataş vd., 2014;). Bu sonuç, hemşirelik öğrencilerin sadece sinava yönelik öğrenme çabası içinde olmadığı, belirli bir hedef doğrultusunda ilerleyerek öğrenmeye meraklı ve ilgili olduklarını düşündürmektedir.

Öğrenmenin gerçekleşmesi, güdülenmenin yanında öğrenme stratejilerinin etkin bir şekilde kullanılmasıyla mümkündür (Karataş vd., 2014). Araştırmamıza katılan öğrencilerin en fazla bilişsel stratejilerden; "düzenleme" ve "yineleme" stratejilerini daha sonra sırasiyla "metabilişsel stratejileri", "eleştirel düşünme”, "zaman ve çalışma ortamı yönetimi”, "emek yönetimi”, "yardım isteme” ve en az da "açımlama stratejisi”ni ve "akran işbirliği yönetimi”ni kullandıkları saptanmıştır. Karataş vd. (2014) tarafindan üniversite öğrencilerinde yapılan çalışmada öğrencilerin en fazla bilişsel stratejilerden; "düzenleme", "yineleme", "açımlama" ve "metabilişsel" stratejileri kullandıkları ve en az da "akran işbirliği" stratejisini kullandıkları saptanmıştır. Çalışmada ilk iki sırada ve son sırada yer alan öğrenme stratejileri dikkate alındığında çalışma sonuçları bizim çalışma sonuçlarımızla benzer niteliktedir. Karakış (2006) tarafından Genel Öğrenme Stratejileri ölçeği kullanarak bazı yükseköğretim kurumlarındaki öğrencilerde yapılan çalışmada ilk üç sırada "dikkat", "bilişş yönetme" ve "anlamlandırma stratejiler"inin kullanıldığı en az olarak "tekrar stratejileri”"nin kullanıldığ1 saptanmıştır. Bruso ve Stefaniak (2016) tarafindan MSLQ ölçeği kullanarak üniversite öğrencileri üzerinde yapılan çalışmada da, öğrencilerin öğrenme stratejilerinden en fazla "açımlama stratejisi"ni, daha sonra sırasıyla "zaman ve çalışma ortamı yönetimi", "eleştirel düşünme", "düzenleme stratejisi", "metabilişsel stratejiler", "emek yönetimi”, "yardım isteme", "yineleme stratejileri"ni ve en az "akran işbirliği yönetimi" stratejisini kullandıkları saptanmıştur. Yapılan çalışmalarda görüldüğü gibi farklı eğitim kurumlarında olan öğrenciler farklı öğrenme stratejileri kullanmaktadırlar. Literatürle parelellik gösteren bir diğer bulgumuz da hemşirelik öğrencilerinin 
Gün, T., \& Denat, Y. (2020). Hemşirelik öğrencilerinin güdülenme ve öğrenme stratejileri. Journal of Human Sciences, 17(1), 32-48. doi:10.14687/jhs.v17i1.5784

daha az kullandıkları öğrenme stratejisinin “akran işbirliği” stratejisi olmasıdır (Karataş vd., 2014). $\mathrm{Bu}$ bulgu öğrencilerin akranları ile işbirliği içinde olacakları çalışma faaliyetlerini daha az tercih ettiklerini göstermektedir. Bireyselleşmenin öne çıtı̆̆ı günümüz toplumundan veya rekabet ortamından kaynaklandığı düşünülen bu bulguların bir ekip çalışması ruhunun önemli olduğu hemşirelik mesleği için kayg1 vericidir. Çalışma sonucunda öğrencilerin en az kullanmayı tercih ettikleri bir diğer strateji olan "açımlama stratejisi” literatür sonuçlarından farklılık göstermektedir (Karataş vd., 2014; Bruso \& Stefaniak 2016). Bu çalışmada öğrencilerin açımlama stratejilerini daha az tercih ediyor olmaları öğrencilerin yeni öğrendikleri bilgiler ile önceki bilgiler arasında bağlantı kurmakta zorlandıklarını ve bilgilerini uzun süreli belleğe aktarmada sıkıntı yaşadıklanını göstermektedir. Bu durum öğrencilerin hala geleneksel öğrenme yöntemlerinden biri olan ezberci öğrenme yöntemlerini kullandıklarını düşündürmektedir.

\section{1. Öğrencilerin Güdülenme Durumlarını Etkileyen Etmenlere İlişkin Bulguların İncelenmesi}

Araştırma kapsamına alınan öğrencilerin cinsiyetlerine göre güdülenme alt boyut puan ortalamaları incelendiğinde; kız öğrencilerin “içsel hedef”, "görev değeri” ve "sınav kaygısı" puan ortalamalarının erkeklerden yüksek, erkek öğrencilerin ise "öğrenme kontrolü inancı" puanlarının kız öğrencilerden daha yüksek olduğu saptanmıştır. Özkan \& Yılmaz (2009)'ın yaptıkları çalışmada, "içsel güdülenme" ve "güdülenme" alt boyutu puan ortalamalarının kız öğrencilerde daha yüksek olduğu bulunmuştur. Özkan vd. (2015)'nın hemşirelik öğrencilerinde yaptıkları çalışmada kızlarda “içsel” ve "dışsal” güdülenme düzeyinin erkeklere göre daha yüksek olduğu belirlenmiştir. Çelik vd. (2014a) yaptuğ çalışmada hemşire öğrencilerin mesleği öğrenmeye ilişkin güdülenmeleri ile cinsiyetleri arasında kız öğrencilerin lehine anlamlı fark olduğu belirlenmiştir. Güdülenmeye ilişkin yapılan diğer çalışmalarda da kız öğrencilerin güdülenme puan ortalamalarının erkeklerden daha yüksek olduğu saptanmıştır (Çiftçi \& Bülbül, 2011; Kulakçı, Ayyıldız, Yıldırım, Veren, Topan, 2015). Bu doğrultuda çalısma bulgularımız literatür bilgisi ile parelellik göstermektedir. Literatürde kaygının düzeyi öğrenmede önemli bir etken olup belli bir düzeyde kaygının öğrenme için güdülenmeyi arttırıcı bir faktör iken yüksek düzeyde bir kaygının öğrenmeyi olumsuz düzeyde etkilediği vurgulanmaktadır (Genç, 2013; Softa, Karaahmetoğlu, \& Çabuk, 2015). Araştırmamızda öğrencilerin güdülenmesinde sınav kaygısının en az etkili olduğu, kız öğrencilerin güdülenmesinde sınav kaygısının erkek öğrencilere göre daha yüksek olduğu belirlenmiştir. Yapılan pek çok çalışmada, sınav kaygısının güdülenmede en az etkili olduğu saptanmış olup (Karataş vd., 2014; Bruso \& Stefaniak, 2016) cinsiyete göre farklılı̆̆a yer verilmemiștir.

Araştırmada 1. sınıf öğrencilerinin “içsel” ve "dışsal hedef" puan ortalamalarının 3.sınıf ve 4. sinıflara göre daha yüksek olduğu, "öz yeterlilik algısı" puan ortalamalarının ise 2., 3. ve 4.sinıflara göre anlamlı derecede daha yüksek olduğu saptanmıştır. Köksal \& Yurttaş (2014)'in hemşirelik öğrencilerinde yaptıkları çalışmada 1. sınıf öğrencilerinin "içsel hedef” puanının, 3. sınıf ve 4. sınıf öğrencilerinden daha yüksek olduğu saptanmıştır. Sağırlı, Çiltaş, Azapağası, \& Zehir (2010) MSLQ kullanarak üniversite öğrencilerinde yaptıkları çalışmada “içsel ve dışsal hedef”, "görev değeri”, “öz yeterlik" alt boyut puan ortalamaları 4. Sinıflara göre 1.sınıflarda anlamlı düzeyde daha yüksek bulunmuştur. Çalışma sonuçları bizim çalışma sonuçlarını destekler nitelikte olup hemşirelik 1.sınıfta öğrenim gören öğrencilerin güdülenmesinde "içsel”, "dışsal hedefler" ve "öz yeterliliğin" etkili olduğu söylenebilir. Birinci sınıf öğrencilerinin yakın bir tarihte üniversite giriş sınavlarına hazırlanmış olmaları ve yeni bir mesleğe adım atmalarının "içsel”, "dışsal hedef" ve "öz yeterlilik" güdülerini etkilediği düşünülmektedir. Ayrıca öz yeterlilik güdüsünün yüksek olmasi 1.sınıfların öğrenmeye verdikleri değer ve herhangi bir işi başarabilmedeki kendilerine güvenleri yönünden daha güdülenmiş olduklarını göstermektedir. Son sınıftaki öğrencilerin güdülenme durumlarının düşük olmasında ise öğrencilerin mesleğe atılmaya yönelik yaşadıkları stres ve iş bulma kaygisı gibi faktörlerin etkili olduğu düşünülmektedir.

Araştırmada hemşirelik mesleğini isteyen ve kısmen isteyenlerin mesleği istemeyenlere göre" görev değeri" puan ortalamaları, hemşirelik mesleğini isteyenlerin mesleği kısmen isteyen ve 
Gün, T., \& Denat, Y. (2020). Hemşirelik öğrencilerinin güdülenme ve öğrenme stratejileri. Journal of Human Sciences, 17(1), 32-48. doi:10.14687/jhs.v17i1.5784

istemeyenlere göre "Öz yeterlilik" ve "sinav kaygisı" puan ortalamalarından daha yüksek saptanmıştır. Çelik vd. (2014a) tarafindan yapılan çalışmada, öğrencilerin ve toplumun mesleğe bakış1, mesleki statü, hemşireliği sevme, hemşirelik mesleğini yapmayı düşünmelerinin mesleki güdülenmede etkili olduğu belirtilmiştir (Çelik vd., 2014a). Özkan \& Yllmaz (2009)'1n yaptığı çalışmada ise hemşirelik öğrencilerinin hemşireliği tercih sırası dokuz ve üstünde olan öğrencilerin içsel güdülenme puan ortalamaları ve okuduğu bölümü aile, öğretmen gibi kişilerin isteği ile seçen öğrencilerin olumsuz güdülenme puan ortalamalarına sahip olduğu belirlenmiştir. Köksal \& Yurttaş (2014)'ın hemşirelik öğrencilerinin mesleki güdülenme düzeylerini belirledikleri çalışmalarında mezuniyet sonrası hemşirelik yapmak isteyenlerin içsel ve dişsal güdülenme alt boyut puan ortalamaları daha yüksek bulunmuştur. Çalışmalarda öğrencilerin güdülenmeleri farklı ölçeklerle ölçüldüğü için çalışma bulguları birbirinden farklı özellikler göstermektedir. Yapılan çalışma sonuçları ve bu çalışmanın sonuçları göstermektedir ki mesleği isteyerek seçme öğrencilerin güdülenmelerini olumlu yönde etkilemektedir. Çalışmamızda hemşirelik mesleğini isteyen öğrencilerin sınav kaygısı yüksek bulunmuştur. Literatürde sınav kaygısı ile meşgul olmanın performans düşüşünün en büyük kaynağı olduğu belirtilmektedir (Duncan \& Mckeachie, 1991).

Çalışmamızda düzenli kitap okuyanların, okumayanlara göre "içsel hedef” ve "öz yeterlilik" puan ortalamaları daha yüksek bulunmuştur. Wang ve Guthire (2004) okuma motivasyonunu içsel ve dişsal motivasyon olarak ele alınmaktadır. Okuma motivasyonu ise önce bireyin okumaya yönelmesi, istekli olması ve zaman ayırmasıdır (Yıldız, 2013). Dolayısı ile çalışmamızda kitap okuyan öğrencilerin içsel hedeflerinin yüksek çıkması okuma motivasyonlarının yüksek olduğunu düşündürmektedir. Akbaba \& Altun (2009) çalışmasında öğretmenlere göre öğrencilerin motivasyon eksikliği nedenlerinden birinin öğrencinin kitap okuma alışkanlığına sahip olmaması ve hedef belirlememiş olmasıdır. Yenice vd. (2012) yaptıkları çalışmada evdeki kitap sayısının öğrencilerin motivasyon düzeylerini saptamada önemli bir faktör olduğu belirlenmiştir. Literatürde yapılan çalışma sonuçları çalışma sonuçları ile paralellik göstermektedir. Sonuçlar kitap okuyan hemşirelik öğrencilerinin içsel hedeflerinin (sorgulama, merak, uzmanlık gibi nedenlerden dolayı bir göreve katulmak için bu görevin kendilerine düssen bir sorumluluk olduğunu algilama durumları) ve öz-yeterliliklerinin (bir görevi yerine getirme kabiliyetine ilisskin bireyin yargılamaları ve bireyin bu görevi yerine getirme becerisine sahip olma durumları) yüksek olduğunu göstermektedir

\section{2. Öğrencilerin Öğrenme Stratejilerini Etkileyen Etmenlere İlişkin Bulguların İncelenmesi}

Çalışmada öğrencilerin cinsiyetlerine göre öğrenme stratejileri alt boyut puan ortalamaları incelendiğinde kız öğrencilerin "açımlama", "düzenleme”, "metabilişsel”, "zaman ve çalışma ortamı yönetimi” puan ortalamalarının erkeklerden daha yüksek olduğu, erkek öğrencilerin ise "akran işbirliği”" puan ortalamalarının kız öğrencilerden daha yüksek olduğu saptanmıştır. Çalışma sonucumuz kız öğrencilerin daha fazla öğrenme stratejisi kullandıklarını ve daha çok "bilişsel" ve "metabilişsel" stratejileri tercih ettiklerini, erkek öğrencilerin ise "kaynak yönetimi" stratejilerini daha fazla tercih ettiklerini göstermektedir. Keklik \& Erdem-Keklik (2012)'in yaptıkları çalışmada kız öğrencilerin "yineleme", "düzenleme", "açımlama", "metabilişsel", "yardım arama", "emek yönetimi" ve "zaman ve çalışma ortamı" stratejileri puan ortalamalarının erkeklerden daha yüksek olduğu belirlenmiştir. Yapılan pek çok çalışma çalışma sonuçlarıyla benzer özellikler göstermekte (Duman, 2008; Güven, 2004; İflazoğlu \& Tümkaya, 2008; Kolody, 1997; Tonguç, 2013) olup k1z öğrenciler daha sistemli, verimli ve planlı bir çalışma düzeni benimsemektedirler. Ülkemizde genelde kız çocuklar yetiştirilirken düzenli ve disiplinli olmaları yönünde görüş hakimdir. Kız çocuklarının yaşam tarzlarındaki düzenliliğin, ders çalışma yöntemlerine ve bilişlerini yönetmelerine yansıdığ1 düşünülebilir. Akran iş birliğinin erkeklerde daha yüksek çıkmasının erkeklerin de kız öğrencilerin düzenli ve disiplinli çalışmasını bilmelerinden dolayı onlarla işbirliği yaparak çalışmalarına teşvik ettiğini düşündürmektedir. Ayrıca Türk Kültüründe erkek çocukları yetiştirilirken takım oyunlarına daha fazla yönlendirilmektedir. Bu durumun da erkeklerin akran işbirliğine yönelmelerinde etkili olduğu düşünülmektedir. 
Gün, T., \& Denat, Y. (2020). Hemşirelik öğrencilerinin güdülenme ve öğrenme stratejileri. Journal of Human Sciences, 17(1), 32-48. doi:10.14687/jhs.v17i1.5784

Çalışmada 1.sınıf öğrencilerinde "açımlama”, "eleştirel düşünme”, "metabilişsel strateji”, "akran işbirliği yönetimi” ve "yardım isteme" puan ortalamaları diğer sınıflara göre daha yüksek bulunmuştur. Bu sonuca göre 1.sınıftaki öğrencilerin kullandıkları öğrenme stratejilerinin özellikleri incelendiğinde öğrencilerin öğrenilecek öğeler arasında bağlantılar kurarak uzun süreli belleğe bilginin toplanmasını sağlama, sorunları çözme, kararlar alma, olayları çok yönlü düşünebilme vb. faktörleri içeren "bilişsel stratejleri” kullandıkları görülmektedir. Bununla birlikte 1. sınıf öğrencileri bilişin farkındalığı, bilgisi ve kontrolü anlamına gelen "metabilişsel” stratejileri kullanmaktadırlar. Bu öğrenciler meslektaşları ile birlikte çalısmanın başarıya olumlu etkileri olacağının farkında olarak akranlarla işbirliği içinde olmanın yanı sıra eğitmenlerinde desteğinin gerekli olduğuna yer verilen kaynak yönetimi stratejilerini de kullanmaktadırlar. Bu stratejilerin hemşirelik eğitiminin başında yer alan öğrenciler tarafindan kullanılıyor olması mesleğin ve mesleki yeterliliğin gelişmesi adına önemli ve sevindirici bir bulgu olup ilerleyen yıllarda öğrencilerin bu stratejileri kullanmadan uzaklaşıyor olmaları mesleki eğitimin yeniden gözden geçirilmesi adına oldukça önemlidir. Yapılan sınırlı sayıdaki bazı çalışmalarda hemşirelik öğrencilerinin öğrenme stratejileri ile sınıfları arasında istatistiksel olarak anlamlı bir fark saptanmamış olup (Çağlayan, Çelik vd., 2014b; Karataş vd., 2014), Hamurcu (2002) tarafindan okul öncesi öğretmen adaylarında yapılan çalışmada bazı öğrenme stratejileri ile sınıflara göre anlamlı farklılık gösterdiği belirtilmiştir. Çalışma sonuçlarının farklı özellikler göstermesinin herbir çalısmada farklı ölçeklerin kullanılması, örneklemde yer alan kurumlardaki eğitim, yöntem ve stratejilerin farklıllğından kaynaklanmış olabileceği düşünülmektedir.

Çalışmada hemşirelik mesleğini istemeyerek seçen öğrencilerin "açımlama”, "düzenleme", "eleştirel düşünme" ve "yardım isteme" stratejilerini, hemşirelik mesleğini isteyen ve kısmen isteyenlerden daha az kullandıkları saptanmıştır. Ayrıca hemşirelik mesleğini isteyen öğrencilerin "metabilişsel" stratejiler ile "zaman ve çalısma ortamı yönetimi" stratejilerini daha fazla kullandıkları saptanmıştır. Görüldüğü gibi hemşirelik mesleğini isteyen öğrenciler bilişin farkındalığı, bilgisi ve kontrolü anlamına gelen, öz düzenlemeye odaklanan, hedef belirleme ve görev analizi gibi planlama faaliyetlerini, daha önceki bilginin ilgili yönlerini etkinleştirmeyi, kendi kendine test etmeyi ve sorgulamayı içeren "metabilişsel stratejileri” kullanmaktadırlar. Ayrıca bu öğrenciler zamanlarını ve çalışma ortamlarını yönetip düzenleyebilmelerini, zamanı etkili bir şekilde kullanmalarını, gerçekçi hedefler belirlemelerini ve çalışma ortamını organize edebilmelerini içeren "zaman ve çalışma ortamı stratejilerini” daha çok kullanmaktadırlar. Hemşirelik mesleğini istemeyen öğrencilerin ise özellikle bilişsel stratejilerin çoğunu daha az kullandıkları görülmektedir. Cry (1998)'in da belirttiği gibi öğrenme stratejilerinin kullanımı güdülenmenin göstergelerinden biridir. Hemşirelik eğitimini isteyerek seçen öğrencilerin de mesleklerini etkin uygulayabilme isteklerinin eğitimlerine daha fazla çaba göstermelerini ve dolayısı ile daha fazla öğrenme stratejisi kullanmalarını etkilediği düşünülmektedir.

Çalışmada düzenli kitap okuyan öğrencilerin "yineleme”, "açımlama”, “düzenleme”, "eleştirel düşünme" ve "metabilişsel" stratejileri düzenli kitap okumayan öğrencilere göre daha fazla kullandıkları saptanmıştır. Görüldüğü gibi düzenli kitap okuyan öğrenciler bilişsel ve metabilişsel öğrenme stratejilerini daha fazla kullanmaktadırlar. Çelik vd (2014b) yaptığ1 çalışmada çok sık kitap okuduğunu belirten öğrencilerin "dikkat" ve "bilişi yönetme" stratejilerini, Güllerci \& Oflaz (2010)'in çalışmalarında ise hatırlama stratejilerini en fazla kullandıkları saptanmıştır. Çöğmen (2008)'in yaptığı çalısmada eğitim fakültesindeki öğrencilerin yılda okudukları kitap sayıları ile strateji kullanma durumları arasında anlamlı bir fark olduğu, kitap okuma sayısı ile strateji kullanımının arttığ1 saptanmıştır. Bizim çalışma sonucumuz da literatür ile parelellik göstermektedir.

\section{Sonuç Ve Öneriler}

Sonuç olarak hemşirelik öğrencilerinin en fazla içsel hedef, en az sınav kaygisı ile güdülendikleri, cinsiyet, sınıf, hemşirelik mesleğini seçmedeki isteklilik ve düzenli kitap okuma alışkanlığının öğrencilerin güdülenme ve öğrenme stratejilerini etkilediği saptandı. Çalışma sonuçları doğrultusunda 2., 3. ve 4. sınıf eğitiminde öğrencilerin güdülenmelerini artırmaya ve öğrenme 
stratejilerini geliştirmeye yönelik eğitim etkinliklerine yer verilmesi, öğrencilerin mesleki güdülenmelerini arttırmak amacıyla seminer, kongre, sempozyum vb. organizasyonların düzenlenmesi ve öğrencilerin bu toplantılara katılımının teşvik edilmesi önerilebilir. Mesleği isteyerek seçmenin öğrencinin güdülenmesini ve doğru strateji seçimini etkilemesi nedeniyle hemşirelik mesleğine ilişkin tanıtıcı çalışmaların yapılması da önemlidir. Çalışma sonuçlarına göre öğrencilerin düzenli kitap okuma alışkanlığı kazanmalanı ve sürdürmelerine yönelik eğitim etkinliklerine yer verilmesi, hemşirelik eğitiminde bilişsel ve metabilişsel öğrenme stratejileri kadar akran iş birliği ve yardım isteme gibi kaynak yönetimi stratejilerini geliştirmeye yönelik eğitim etkinliklerinin düzenlenmesi de önerilebilir.

\section{Kaynakça}

Acat, M.B., \& Köşgeroğlu, N. (2006). Güdülenme kaynakları ve sorunları ölçeği. Anadolu Psikiyatri Dergisi, 7(4), 204-10.

Akbaba Altun S. (2009). An investigation of teachers', parents', and students' opinions on elementary students' academic failure. Elementary Education Online, , 8(2), 567-586.

Bruso, J.L., \& Stefaniak, J.E., (2016). The use of self-regulated learning measure questionnaires as a predictor of academic success. Association for Educational Communications \& Technology, 60, 577-584.

Büyüköztürk, Ş., Akgün, Ö.E., Özkahveci, O., \& Demirel, F. (2004). Güdülenme ve öğrenme stratejileri ölçeğinin türkçe formunun geçerlik ve güvenirlik çalışması, Kuram ve Uygulamada Eğitim Bilimleri, 4 (2), 207-239.

Cesur, M.O. (2008). Üniversite hazırllk sinıf ögrencilerinin yabancı dil ögrrenme stratejileri, ögrrenme stili tercibi ve yabanc dil akademike başarısı arasındaki açıklayıcı ve yordaync ilişkiler örüntüsü (Yayınlanmamış Doktora Tezi). Yıldız Teknik Üniversitesi, İstanbul.

Cook, D.A., Thompson, W.G., \& Thomas, K.G. (2011). The Motivated Strategies for Learning Questionnaire: score validity among medicine residents. Medical Education, 45, 1230-1240.

Cry, P. (1998). Les strategies d'apperentissage. Paris: Cle'International.

Çağlayan, H.S., Şirin, E.F.,\& Yıldız, Ö. (2008). Beden eğitimi ve spor yüksekokulu öğrencilerinin genel öğrenme stratejilerini kullanma düzeylerinin bazı değişkenlere göre incelenmesi. Türkiye Sosyal Arastirmalar Dergisi, 12(2), 45-62.

Çakmak, E.K., Akgün, Ö.E, Karadeniz, Ş., Büyüköztürk, Ş., \& Demirel, F. (2008). İlköğretim ikinci kademe ve lise öğrencilerinin ders ve sınıf düzeylerine göre öğrenme stratejileri ve güdülenme düzeylerinin belirlenmesi. Uluslararası İnsan Bilimleri Dergisi, 5(1), 1-26.

Çelik, S., Şahin, E., Dadak, F., Sıdal, S.G., \& Akyüz, F. (2014). Hemşirelik öğrencilerinin mesleki güdülenme düzeyleri ve etkileyen faktörler. Journal of Health Science and Profession, 1(2), 4356.

Çelik, S., Yıldırım, D., Batur, Ö., Çime, E., Çapraz, F., \& Kubat, N. (2014). Öğrenci hemşirelerin öğrenme stratejileri ve stillerinin belirlenmesi. Ankara Sağllk. Hižmetleri Dergisi, 13(1),13-27.

Çiftçi, G., \& Bülbül, S. (2011). Sağlık Bilimleri Fakültesini Tercih Eden Öğrencilerin, Üniversite ve Meslek Tercihlerinde Etkili Olan Faktörler. Kartal Eğitim ve Araştorma Hastanesi Tip Dergisi, 22(3),151-160.

Çöğmen, S. (2008). Eğitim Fakültesi Öğrencilerinin Kullandıklar Okuduğunu Anlama Stratejileri (Yayınlanmamış Yüksek Lisans Tezi). Adnan Menderes Üniversitesi, Aydın.

Deryakulu, D. (2004). Üniversite öğrencilerinin öğrenme ve ders çalışma stratejileri ile epistomolojik inançları arasındaki ilişki. Kuram ve Uygulamada Eğitim Yönetimi, 38, 230-249.

Dikmen, Y. (2015). Kolb’un öğrenme stilleri modeline göre hemşirelik öğrencilerinin öğrenme stillerinin incelenmesi. Journal of Human Rhythm, 1(3), 101-106.

Duman, B. (2008). Öğrencilerin benimsedikleri eğitim felsefeleriyle kullanıldıkları öğrenme strateji ve öğrenme stillerinin karşılaştırılması. Cukurova Üniversitesi Sosyal Bilimler Enstitüsü Dergisi, 17(1), 203-224. 
Gün, T., \& Denat, Y. (2020). Hemșirelik öğrencilerinin güdülenme ve öğrenme stratejileri. Journal of Human Sciences, 17(1), 32-48. doi:10.14687/jhs.v17i1.5784

Duncan, T.G., \& McKeachie, W.J. (1991). A Manual for the Use of the Motivated Strategies for Learning Questionnaire (MSLQ). Retrieved from https:// www.researchgate.net/publication/271429287

El-Gilany, A.H., \& Abusaad Fel, S. (2013). Self-directed learning readiness and learning styles among saudi undergraduate nursing students. Nurse Education Today, 33(9), 1040-1044.

Erdem, A.R. (2005). Etkili ve Verimli-Nitelikli- Eğitim. Ankara: Anı Yayıncilık.

Espeland, V., \& Indrehus, O. (2003). Evaluation of students, satisfaction with nursing education in Norway. Journal of Advanced Nursing, 42(3), 226-237.

Garcia, T.,\& Pintrich, P. (1995). Assessing Students' motivationand learning strategies: the motivated strategies for learning questionnaire, American Educational Research Association, $18-22$.

Genç, M. (2013). İlköğretim öğrencilerinin sinıf ve cinsiyete göre sinav kayg1 düzeylerinin belirlenmesi. Sosyal Bilimler Dergisi, 11(1), 85-95.

Gopee, N. (2002). Human and social capital as facilitators of life long learning in nursing. Nurse Education Today, 22, 608-616.

Güllerci, H., \& Oflaz, F. (2010). Ambulans ve acil bakım teknikerliği eğitimi alan öğrencilerin öğrenme stil ve stratejilerinin incelenmesi. Gülhane T⿰力 Dergisi, 52, 112-120.

Güven, M. (2004). Öğrenme stilleri ile ögrrenme stratejileri arasindaki ilişki ( Yayınlanmamış Doktora Tezi). Anadolu Üniversitesi, Eskişehir.

Güven, M., \& Kurum, D. (2006). Öğrenme stilleri ve eleştirel düşünme arasındaki ilişkiye genel bir bakış. Sosyal Bilimler Dergisi, 1, 75-89.

Hamurcu, H. (2002). Okul öncesi öğretmen adaylarının kullandıkları öğrenme stratejileri. Hacettepe Üniversitesi Eğitim Fakültesi Dergisi, 23, 127-134.

Higgins, E.T., \& Kruglanski, A. (2000). Motivational science: The nature and functions of wanting. In E. T. Higgins \& A. Kruglanski (Eds.), Motivational science: Social and personality perspectives. Philadelphia: Psychology Press.

İflazoğlu, S. A., \& Tümkaya, S. (2008). Öğretmen adaylarının öğrenme stratejileri ile sosyo demografik özellikler ve akademik başarıları arasındaki ilişkinin incelenmesi. Ege Eğitim Dergisi, (9)1, 1-22.

Karakış, Ö. (2006). Baそ̣ yükseköğrenim kurumlarnda farkli ögrenme stillerine sabip olan ögrrencilerin genel ögrenme stratejilerini kullanma düreyleri (Yayınlanmamış Yüksek Lisans Tezi). Abant İzet Baysal Üniversitesi, Bolu.

Karataş S, Güleș H, Aypay A. Üniversite Öğrencilerinin Öğrenmeye Yönelik Güdülenmeleri ve Kullandıkları Öğrenme Stratejileri, Eğitimde Politika Analizi Dergisi, 2014, 3(2), 31-48.

Kaya, H.,\& Akçin, E. (2002). Öğrenme biçimleri, stilleri ve hemşirelik eğitimi. Cumburiyet Üniversitesi Hemşirelik. Yüksekokulu Dergisi, 6(2), 31-35.

Keklik, İ., \& Erdem-Keklik, D. (2012). Examination of High School Students' Motivationand Learning Strategies. Hacettepe Egitim Journal of Education, 42, 238-249.

Kelecioğlu, H. (1992). Güdülenme. Hacettepe Üniversitesi Ë̆itim Fakültesi Dergisi, 7, 175-181.

Kolod, R. C. (1997). Learning strategies of Alberta college students (Unpublished Doctoral Dissertation). Montana State University: Bozeman.

Köksal, L.G., \& Yurttaş, A. (2014). Hemşirelik öğrencilerinin mesleki güdülenme düzeyleri, Balıkesir Sağhlk Bilimleri Dergisi, 4(1), 10-15.

Kulakçı, H., Ayyıldız, T.K., Yıldırım, N., Veren, F., \& Topan, A.K. (2015). Motivational resources and problems of nursing students: vocational choice, school culture and other associated factors, Sağhle ve Hemsirelike Yönetimi Dergisi, 2 (2), 83-93.

Özen, Y. (2011). Sosyal bilgiler eğitimi öğretmenliği öğrencilerinin öğrenme stilleri ve bunların çeşitli değişkenlerle ilişkisi (Erzincan Üniversitesi örneği). Uluslararası Hakemli Sosyal Bilimler E-Dergisi, Akademik Bakız̧ Dergisi, 24(2), 1-20.

Özer, B. (1998). Ögrenmeyi Öğretme. Eğitim Bilimlerinde Yenilikler. Hakan, A. (Editör),. Anadolu Üniversitesi Açı Öğretim Fakültesi Yayınları, Eskişehir. 
Gün, T., \& Denat, Y. (2020). Hemșirelik öğrencilerinin güdülenme ve öğrenme stratejileri. Journal of Human Sciences, 17(1), 32-48. doi:10.14687/jhs.v17i1.5784

Özkan, N.Ö., Akın, S., \& Durna, Z. (2015). Hemşirelik öğrencilerinin liderlik yönelimleri ve motivasyon düzeyleri. Hemşirelikte Ë̆itim ve Araștirma Dergisi, 12 (1), 51-61.

Özkan, S., \& Yılmaz, E. (2009). Hemşirelik öğrencilerinin güdülenme düzeylerinin belirlenmesi. Ege Üniversitesi Hemsirelik. Yükesek Okulu Dergisi, 25(3), 55-68.

Pintrich, P., Smith, D. A. F., Garcia, T., McKeachie, W.J. (1991). A Manual for the Use of the Motivated Strategies for Learning Questionnaire (MSLQ), Michigan: School of Education Building, The University of Michigan.

Pintrich, P.R., Smith, D.A.F., Garcia, T., \& Mckeachie, W.J. (1993). Reliability and predictive validity of the motivated strategies for learning questionnaire (MSLQ). Educational and Psychological Measurement, 53(3), 801-813.

Sağırlı, M.Ö., Çiltaş, A., Azapağası E., \& Zehir, K. (2010). Yüksek öğretimin öz-düzenlemeyi öğrenme becerilerine etkisi (Atatürk Üniversitesi Örneği). Kastamonu Eğitim Dergisi, 18(2), 587-596.

Sarmasoğlu, Ş., \& Görgülü, S. (2014). Hemşirelik öğrencilerinin kendi kendine öğrenmeye hazıroluş düzeyleri. Hacettepe Üniversitesi Hemşirelik Fakültesi Dergisi, 13-25.

Seven, M., Bağcivan, G., Kılıç, S., \& Açıkel, C. (2012). Hemşirelik yüksekokulu birinci sınıf öğrencilerinin öğrenme stillerinin belirlenmesi ve ders başarıları ile ilişkisinin incelenmesi. Gülhane T⿰亻 Dergisi, 54, 129-135.

Smedley A. (2007). The self-directed learning readiness of first year bachelor of nursing students. Journal of Research in Nursing, 12, 373-385.

Softa, H.K., Karaahmetoğlu, G.U., \& Çabuk, F. (2015). Lise Son Sınıf Öğrencilerinin Sınav Kaygisı ve Etkileyen Faktörlerin İncelenmesi, K. Ü. Kastamonu Ĕ̈itim Dergisi, 23 (4), 1481 1494.

Şenyuva, A.E. (2009). Hemşirelik öğrencilerinin öğrenme stillerinin bazı değişkenler açısından incelenmesi. Kuram ve Uygulamada Eüitim Yönetimi, 15(58), 247-271.

Şenyuva, E. (2013). Hemşirelikte Yaşam Boyu Öğrenme: Algılar ve Gerçekler. Florence Nightingale Hemsirelik Dergisi, 21(1), 69-75.

Titmus, C. (1999). Concepts and practices of education and adult education: Obstacles to life long education and life long learning. International Journal of Lifelong Education, 18(3), 343354.

Tonguç, D. (2013). Sekiz̨inci smif ögrencilerinin motivasyon düzeylerinin ve öz-düzenlemeye dayal ögrenme stratejilerinin matematike başarısın yordama gücü (Yayınlanmamış Yüksek Lisans Tezi) Eskişehir Osmangazi Üniversitesi, Eskișehir.

Uyulgan, M.A., \& Akkuzu, N. (2014). An overview of student teachers' academic intrinsic motivation. Educational Sciences: Theory \& Practice, 14(1), 24-32.

Veznedaroğlu, R.L., \& Özgür, A.O. (2005). Öğrenme stilleri: tanımlamalar, modeller ve işlevleri. Illkögrretim Online, 4(2), 1-16.

Wang, J.H., \& Guthire, T.J. (2004). Modeling the effect of intrinsic motivation, extrinsic motivation, amount of reading, and past reading achievement on text comprehension between U.S. and Chinese students. Reading Research Quarterly, 39, 2, 162-186.

Yavuzalp, N. (2012). E-Öğrenme ortamında kullamlan ögrenme stil ve stratejilerinin web kullanım madenciliği ile analiz̨ (Yayınlanmamış Doktora Tezi), Fırat Üniversitesi; Elazığ.

Yenice, N., Saydam, G., \& Telli, S. (2012). İlköğretim Öğrencilerinin Fen Öğrenmeye Yönelik Motivasyonların Etkileyen Faktörlerin Belirlenmesi. Ahi Evran Üniversitesi Kırşehir Eğitim Fakültesi Dergisi, 13(2), 231-247.

Yıldız, M. (2013). Okuma motivasyonu, akıcı okuma ve okuduğunu anlamanın beşinci sınıf öğrencilerinin akademik başarılarındaki rolü. International Periodical For The Languages, Literature and History of Turkish or Turkic, 8(4), 1461-1478.

Yuan, H.B., Wiliams, B.A., Fang, J.B., \& Pang, D. (2012). Chinese baccalaureate nursing students' readiness for self directed learning. Nurse Education Today, (32), 427-431. 


\section{Extended English Summary}

\section{Introduction}

In order for students to take responsibility and take an active role in the learning process, they need to be motivated and aware of their own learning strategies. The aim of this research is to determine the nursing students' motivation and learning strategies with the affecting factors.

\section{Method}

This research is a descriptive and analytical study conducted in order to determine the nursing students' motivation and learning strategies with the affecting factors.

\section{Universe and Sample}

The population of the study consisted of the students who are studying at nursing department of one university in the west of Turkey. There were 849 students in the department. No sample selection was made in the research and it was aimed to reach the whole population. The sample of the study consisted of a total of 648 nursing students who volunteered to participate in the study, who attend the courses and completed the data collection form. Achieved $76 \%$ of the universe.

\section{Data collection}

Data collection was carried out using the "Student Information Form" and "Scale of Motivation and Learning Strategies".

\section{Analysis}

Kolmogorov-Smirnov, Mann-Whitney U, Kruskal Wallis test, One-way Analysis of Variance, Spearman test, Tamhane test, multiple comparison test (pairwise comparisons) were used for the analysis of the data.

\section{Results}

It was found that the average age of students in study was $20.80 \pm 1.48,64 \%$ of students were female. It was determined that $20.8 \%$ of the students participating in the research were in the first grade, $30.4 \%$ were in the second grade, $35.8 \%$ were in the third grade and $13 \%$ were in the fourth grade. It was determined that $38.1 \%$ of the students who participated in the study voluntarily chose the nursing profession, $28.1 \%$ did not willingly choose the profession, and $33.8 \%$ partially voluntarily chose the nursing profession. It was determined that $42.9 \%$ of the students included in the study read books regularly, 57.1\% did not read books regularly.

Average scores of intrinsic goal orientation, task value and test anxiety in female students and control beliefs in male students were found to be significantly high $(\mathrm{p}<0.05)$ in the study. The intrinsic and extrinsic goal orientation score averages of the 1st-grade students were found to be significantly higher than the 3rd and 4th graders and their self-efficacy for learning and performance score averages were found to be higher than of the 2 nd 3 rd and 4th graders. The perception of self-efficacy for learning and performance and test anxiety of students graduated from medical vocational high school, test anxiety of students who perceive their economic situation as having more income than expenditure, intrinsic goal orientation and self-efficacy for learning and performance of the students who live alone, task value of students who chose nursing profession willingly or partially willingly, the self-efficacy for learning and performance and test anxiety of those willing the profession of nursing, the intrinsic goal orientation, task value, control beliefs and test anxiety of those who are satisfied with nursing education, of those reading books regularly the intrinsic goal orientation and self-efficacy for learning and performance score averages were found to be significantly high. The elaboration and organization, metacognitive self-regulation, time and study environment strategy average scores 
of the female students participating in the study, and peer learning average scores of the male students participating in the study were found to be significantly high. The average scores of elaboration and critical thinking, metacognitive self-regulation, peer learning and help-seeking of the 1st grade students, effort regulation of the students graduated from medical vocational high school, critical thinking strategy, time and study environment and effort regulation of the students who perceive their economic situation as the income being equal to the expenditure, effort regulation strategy of the students living alone, help-seeking strategy of the students living with their friends, rehearsal, elaboration, organization, critical thinking and metacognitive selfregulation of the student who read books regularly were found to be significantly high. Elaboration, organization, critical thinking and help-seeking score averages of those who did not choose the nursing profession willingly were found to be significantly low $(p<0.05)$.

\section{Conclusion}

As a conclusion, it was found that the nursing students have been motivated mostly by intrinsic goal orientation and least motivated by test anxiety. Moreover, it was noted that gender, graduated school, perceived economic status, accommodation, willingness in choosing nursing profession, level of satisfaction from the education and habit of reading books regularly have affected the students' motivation and learning strategies. It is considered that this research will constitute data for other studies and it will be as a guide for the organization of nursing education activities, fulfilling educational goals and providing quality education. 